\title{
INCREASING SKILLS READING STUDENTS THROUGH GUIDANCE AND COUNSELING CLASSICAL USING CTL APPROACH
}

\author{
Romi Fajar Tanjung ${ }^{1}$ Neviyarni Neviyarni ${ }^{2}$ Firman Firman ${ }^{3}$ \\ ${ }^{123}$ Universitas Negeri Padang \\ Corresponding author, e-mail: romifajarr@gmail.com
}

\begin{abstract}
The condition of students learning skill is still classified as moderate category. One of the learning skills is the reading skill. The phenomenon seen in the field that the students interest in reading is high, but endurance in reading is low. The purpose of this study is to improve students reading skills through classical guidance and counseling using Contextual Teaching and Learning (CTL) approach. This research is using experimental method. The study population is a student of Faculty of Education. The sample of the research is a student of Guidance and Counseling. The sampling technique uses cluster sampling. Data analysis using Kolmogorov Smirnov 2 Independent Sampels. The result of the research found that classical guidance and counseling using Contextual Teaching and Learning (CTL) approach is effective to improve students' reading skill.
\end{abstract}

Keyword: Reading Skill, Guidance and Counseling, Contextual Teaching and Learning

\section{Introduction}

The mastery of learning skills will facilitate the students in the process of following the pngelajaran in college. Students who do not have the skills to study in the high category, the students will have difficulty undergoing lectures, the potential is not developed, and failing in universities (Zahri, Yusuf \& Neviyarni, 2017).

One of the learning skills is the reading skill. Reading skills very important in the success of education, as well as career student in the future. Poor reading ability tends to have a significant postschool impact (McGeown, Duncan, Griffiths, \& Stothard, 2014).

The phenomenon in the field we find that interest in reading students is generally high but their reading endurance is low. This can be found, when a student reads a chat or news on social media, he or she will be enthusiastic and read enthusiastically when the text or information is short, if the information is too long, the student will be lazy to read it. The results of the study found, in general today's teenagers more to spend time with the activity of reading chat, internet, social media, and email (Pitcher et al., 2007; Clark, 2011).

Reading is an activity that requires focus, interest and continuous effort. Then motivasition in reading more contributing to improving reading skills than cognitive ability (Taboada, Tonks, Wigfield \& Guthrie, 2009; Anmarkrud \& Bråten, 2009; Logan, Medford \& Hughes, 2011; Medford \& McGeown, 2011). In addition, self-reading activities tend to be able to develop a variety of reading skills (Mol \& Bus, 2011).

One of the components that need to be considered in reading skills is the level of reading speed, in addition to vocabulary and comprehension. The reading skill level is reviewed from various components such as vocabulary, comprehension, summarizing skills and speed reading text is very different for everyone. All these components is an essential element for improving reading skills (McGeown, Duncan, Grifths, \& Stothard, 2014).

One way to improve learning skills is to increase motivation, increase interest in reading, to feel that reading something fun activities (Wigfield \& Eccles,2000; Morgan \& Fuchs, 2007). Good readers , 
more dominantly have intrinsic motivation in reading, such as thinking reading is a need and a fun thing. While the worse readers are more dominant extrinsic motivations, such as reading to get good grades (Lau \& Chan, 2003; McGeown, Norgate \& Warhurst, 2012).

Students who have high internal motivation to read, then the student will consider reading activity is a requirement and a fun activity for him. If reading is more dominant than external motivation, then reading activity is only an activity to release responsibility and reading activity has no meaning in life.

CTL is a comprehensive approach that resembles the workings of nature, and unifies concepts and practices (Johnson, 2014). CTL is an innovative instructional toolkit (Sears \& Hersh, 2000; Sears, 2002; Johnson, 2014), whose work of building student constructiveness such as critical thinking, inquiry learning, problem solving is related to the actual context, relevant intellectual and social (Brown, 2000; Ca vallo, Miller, \& Saunders, 2002).

CTL aims to enable students to understand the meaning of knowledge and skills so as to guide students in the mastery of knowledge and skills. CTL approach has seven steps: constructivism, questioning, inquiry, learning community, modeling, reflection, and authentic assessment (Sumiati \& Asra, 2007).

CTL can enhancing motivation of learners and to make what they learn and apply to be meaningful in the context of actions and interactions in their everyday situations (Ilhan, Yildirim, \& Yilmaz, 2016). Students are invited to learn through experience rather than just memorizing but more meaningful than just memorizing (Jauhari, 2011).

The use of the ontextual approach can enhance the learning process for transferring learned information in a good classroom setting as well as linking material to real-life situations (Shamsid-Deen, 2006). The contextual approach method enables students to be active, view relevant learning, mutual learning, relate material to the real world or the experience of students and educators acting as facilitators (Smith, 2010).

\section{Method}

This research uses experimental method. The study population is the faculty of science education. The sample of the research is guidance and counseling students. The sampling technique uses cluster sampling. The experimental samples were divided into two groups aimed at looking at the consistency of the treatment. Both groups were given counseling guidance treatment by using classical approach contextual teaching and learning (CTL). The number of sample group 1 is 22 students and group 2 is 22 students. The instrument used is RFN reading skill instrument in adaptation of Nurhadi theory (2016). Treatment is given four times during one month. Data analysis using Kolmogorov Smirnov 2 Independent Sampels to see the consistency of treatment effect.

\section{Results and Discussion \\ Results}

After the research it was found that the student's skill level was very low. Below we will describe the data about the students' reading skill level.

Table 1. Classification of Student Speed Rate at Pretest and Posttest

\begin{tabular}{llcccc}
\hline \multirow{2}{*}{ Interval } & \multirow{2}{*}{ Category } & \multicolumn{2}{c}{ Group 1 } & \multicolumn{2}{c}{ Group 2 } \\
\cline { 3 - 6 } & & Pretest & Posttest & Pretest & Posttest \\
\hline $311-325$ & Very high & 0 & 7 & 0 & 12 \\
$296-310$ & High & 3 & 2 & 0 & 2 \\
$281-295$ & Medium & 0 & 2 & 0 & 4 \\
$266-280$ & Low & 2 & 3 & 0 & 1 \\
$250-265$ & Very low & 17 & 8 & 22 & 3 \\
\hline & Total & 22 & 22 & 22 & 22 \\
\hline
\end{tabular}

Table 1 above is found in group 1 there are 19 people who have learning skills that are in the category under moderate. While in group 2 it was found that all students had reading skill which was in very low category. After treatment of both groups, students' reading skill increased. The result of posttest 
was found in group 1 there were 14 people have reading skill in category above medium, whereas in group 2 , there were 12 people have reading skill in category above medium.

\section{Graph 1. Level of Student Reading Speed Group 1}

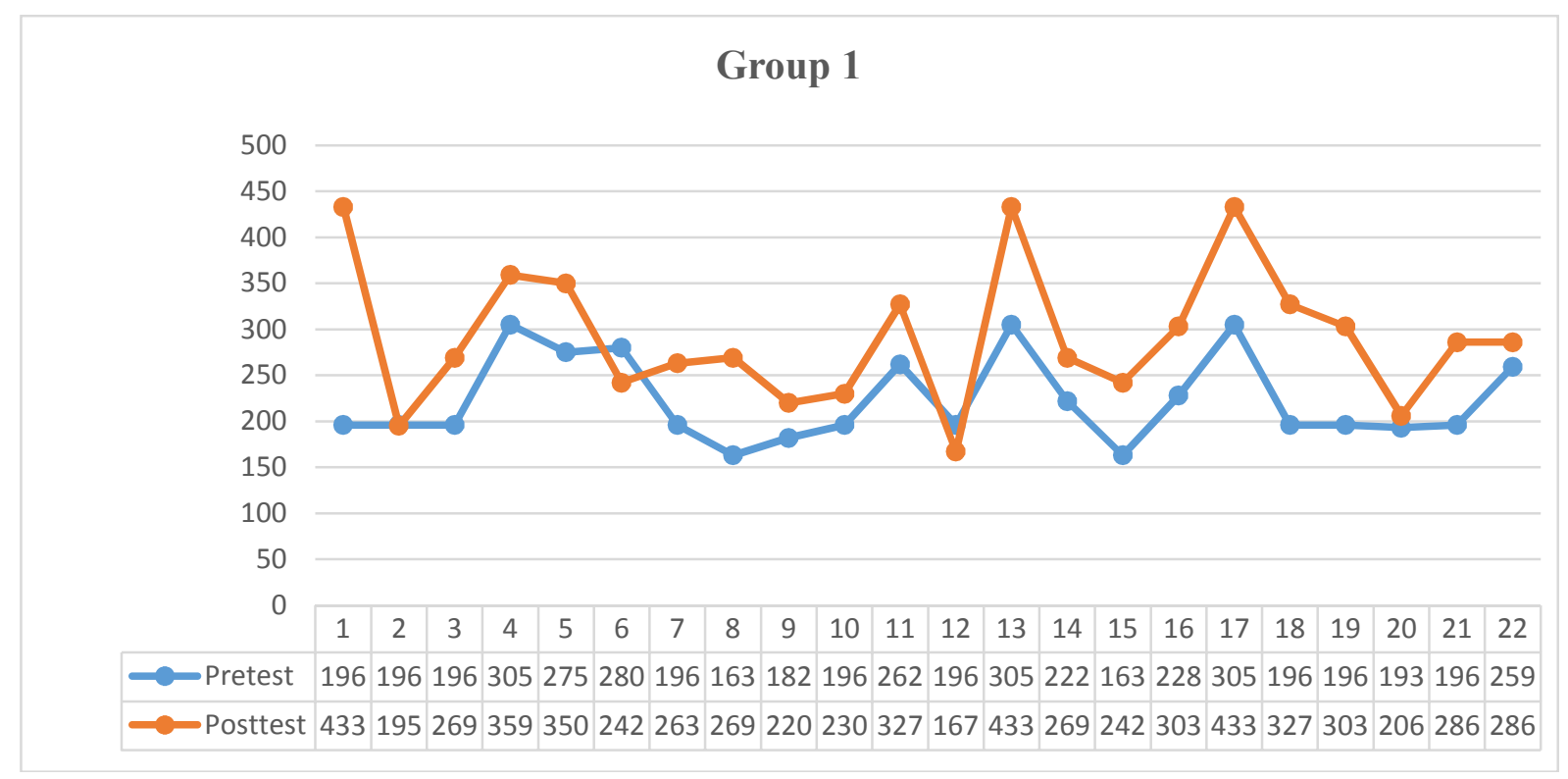

Based on graph 1 above, it was found that all respondents experienced improvements in reading skills after being given material training on effective and efficient techniques. Average increase in reading speed of group 1 students by 68 scores.

\section{Graph 2 . Level of Student Reading Speed Group 2}

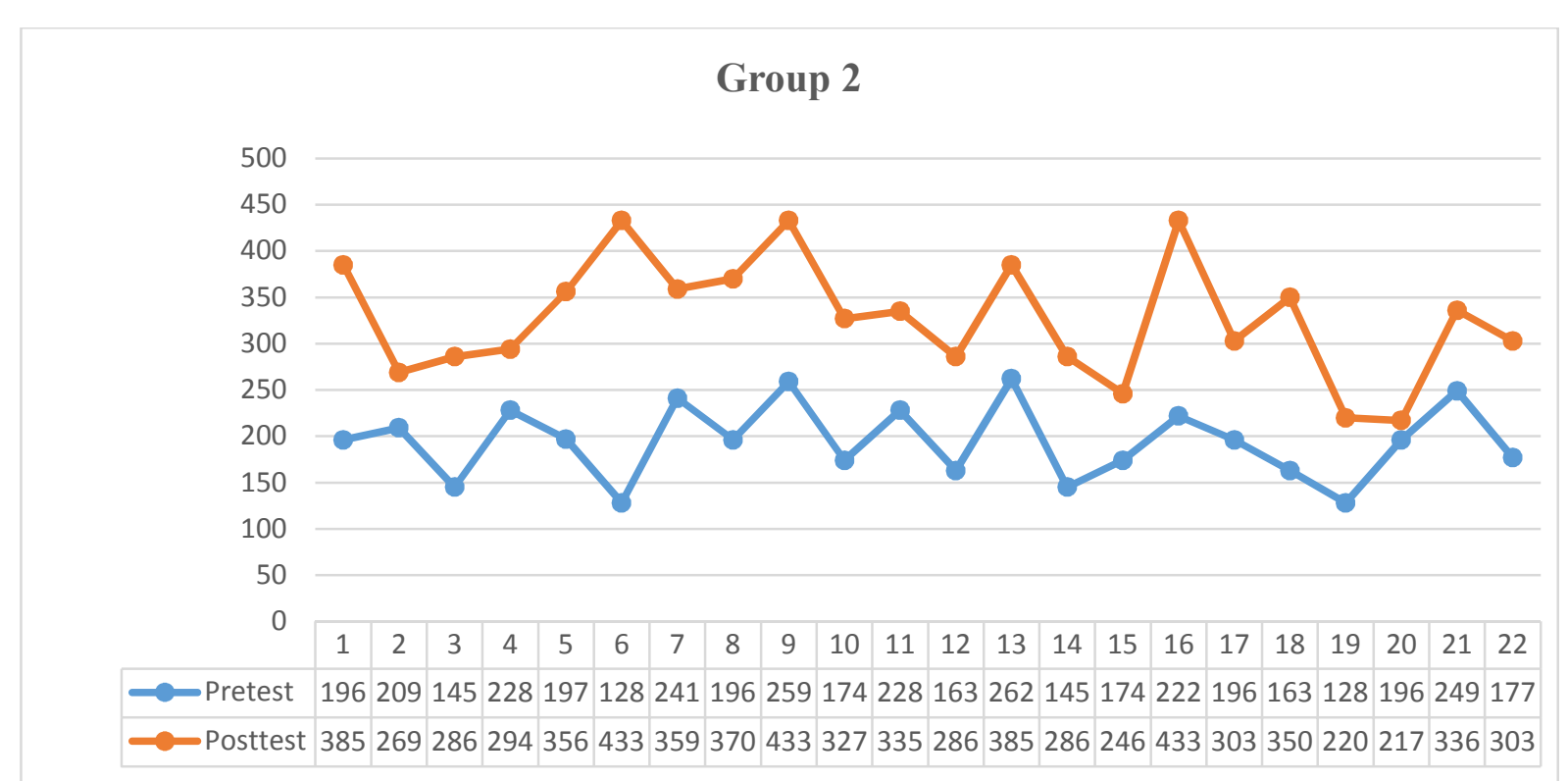

Based on graph 2 above found that all respondents experienced improvements in reading skills after being given material training on effective and efficient reading techniques. The average increase in reading speed of group 2 students was 133 scores. 
Table 2. Different Test Results Group 1 with Group 2

\begin{tabular}{llr}
\hline & & Speed Reading \\
\hline Most Extreme Differences & Absolute & .318 \\
& Positive & .318 \\
& Negative & .000 \\
\hline Kolmogorov-Smirnov Z & & 1,055 \\
\hline Asymp. Sig. (2-tailed) & & .215 \\
\hline
\end{tabular}

Kolmogorov-Smirnov Z test results found that Asymp. Sig. (2-tailed) of 0.215. The significance value of 0.215 is greater than the significant value $0.05(0.215>0.05)$. This means that the results of the two groups posttest the same, means counseling guidance services classically with contextual teaching and learning approach (CTL) gives the same effect in both groups. Thus guidance and counseling by using a contextual teaching and learning approach (CTL) is effective to improve students' reading skills in college .

\section{Discussion}

Good reading speed, enables students to absorb a lot of information with a very short time. Conversely, low reading speed will take a lot of time to absorb or complete a reading so that activity is ineffective.

The results were found that there is a significant relationship between reading ability with reading motivation and reading frequency (Wang \& Guthrie, 2004; Morgan \& Fuchs, 2007; Taboada et al., 2009; Becker, McElvany \& Kortenbruck, 2010; Logan \& Medford, 2011; Logan et al., 2011). By increasing the motivation and reproduce reading then the skills of reading by itself will increase, one of which speed in reading is increasing.

The results of research found one of the factors of students have low reading speed because students do not know the techniques or strategies to read effectively and efficiently, reading activities are low and have less interest in reading especially long texts. The results of the study explain that children and adolescents who are more often involved in reading activities have better literacy skills (Leppanen, Aunola \& Nurmi, 2005; Mol \& Bus, 2011).

Based on this, then a student must revive the culture of reading especially the scientific books and able to survive to read scientific writings long enough. Durability when reading is very important, to eliminate feeling lazy when it is faced with long writings. Then the speed of reading is necessary, so that students do not spend too much time when reading.

The results of the study found that in general the reading speed of students is very low. So the need for a treatment to assist students in improving their reading skills. One alternative that can be done is to implement guidance and counseling service by using a classical approach contextual teaching and learning (CTL).

Contextual approach methods help educators motivate students to make connections between subject matter content and real- life situations. Context for subject content can scope up categories of realworld, personal, community, work, and scientific contexts (OECD, 2013).

The results of the study of two groups found that both groups experienced improved reading skills. Group 1 had an average score before treatment was given 223, after the average score of reading rate was 291. Group 2 had an average score before treatment was given 194, after the average treatment of reading speed was 328 .

Then the result of posttest test of both groups by using Kolmogorov-Smirnov $Z$ showed significance value of $\mathrm{Z}$ greater than 0.05 that is $0.215(0.215>0.05)$. This means that the result of improving the reading skill that occurs in both groups is the same. Thus guidance and counseling with contextual teaching and learning approach is effectively to improve student's learning skill.

The results of another study also found that guidance and counseling in the classical with contextual teaching and learning approach is effective in reducing the hedonism of the student's lifestyle (Hasibuan, Firman, \& Ahmad, 2016), and decreasing the student's tendency toward pornography (Asmidaryani, Firman, Gistituati, 2018). Then the CTL approach can improve the outcomes of chemistry higher than the conventional approach (Fadillah et al., 2017). 


\section{Conclusion}

1. Student reading skills are generally still in very low categories. Reading skills is one of the learning skills that need to be mastered by a student in order to follow the learning process optimally.

2. Reading skills are one of the decisive factors or that contribute to achieving student achievement

3. Classical counseling and counseling services are effective for improving students' reading skills.

\section{Acknowledgment}

Acknowledgments I say to the supervisor who has contributed through the energy and mind in this research. thanks to the head of the guidance and counseling department who has provided an opportunity to conduct research on guidance and counseling students. Thanks to my friends for helping me with my research. Then thanks to the guidance and counseling students who have been willing to be a sampel of this study.

\section{References}

Anmarkrud, O., \& Braten, I. (2009). Motivation for reading comprehension. Learning and Individual Differences, 19(2), 252-256.

Asmidaryani, Firman, Gistituati, N. (2018). The effectivenes of layanan informasi using contextual teaching and learning (CTL) approach to degree of students pornography trends. Proceeding International Conferences on Educational, Social Sciences and Technology, 133-144.

Becker, M., McElvany, N., \& Kortenbruck, M. (2010). Intrinsic and extrinsic reading motivation as predictors of reading literacy: A longitudinal study. Journal of Educational Psychology, 102(4), 773785 .

Brown, F. (2000). The effect of an inquiry-oriented environmental science on preservice elementary teachers' attitudes about science. Journal of Elementary Science Education, 12(2), 1-6.

Cavallo, A. M. L., Miller, R. B., \& Saunders, G. (2002). Motivation and affect toward learning science among elementary school teachers: Implications for classroom teaching. Journal of Elementary Science Education, 14(2), 25-38.

Clark, C. (2011). Setting the Baseline. The National Literacy Trust's first annual survey into young people's reading. National Literacy Trust.

Fadillah, A., Dewi, N. P. L. C., Ridho, D., Majid, A. N., \& Prastiwi, M. N. B. 2017. The effect of application of contextual teaching and learning (CTL) model-based on lesson study with mind mapping media to assess student learning outcomes on chemistry on colloid systems. International Conference on Science and Applied Science, 1(2), 101-108.

Hasibuan, M. F., Firman, \& Ahmad, R. (2016). Efektivitas layanan informasi dengan menggunakan pendekatan contextual teaching and learning dalam mengurangi sikap siswa terhadap gaya hidup hedonisme. Jurnal Penelitian Pendidikan Indonesia, 2(1), 1-11.

Ilhan, N., Yildirim, A., \& Yilmaz, S. S. (2016). The effect of context-based chemical equilibrium on grade 11 students' learning, motivation and contructivist learning environment. International Journal of Environment \& Science Education, 11(9), 3117-3137.

Jauhari, M. (2011). Implementasi PAIKEM. Jakarta: Prestasi Pustakaraya.

Johnson, E. B. (2014). Contextual Teaching and Learning: Menjadikan Kegiatan Belajar Mengajar Mengasyikkan dan Bermakna. Terjemahan Ibnu setiawan. Bandung: Kaifa. 
Lau, K., \& Chan, D. W. (2003). Reading strategy use and motivation among Chinese good and poor readers in Hong Kong. Journal of Research in Reading, 26(2), 177-190.

Leppanen, U., Aunola, K., \& Nurmi, J.-E. (2005). Beginning readers' reading performance and reading habits. Journal of Research in Reading, 28(4), 383-399.

Logan, S., \& Medford, E. (2011). Gender differences in the strength of association between motivation, competency beliefs and reading skill. Educational Research, 53(1), 85-94.

Logan, S., Medford, E., \& Hughes, N. (2011). The importance of intrinsic motivation for high and low ability readers' reading comprehension performance. Learning and Individual Differences, 21(1), 124128.

McGeown, S. P., Duncan, L. G., Griffiths, Y. M., \& Stothard, S. E. (2014). Exploring the relationship between adolescent's reading skills, reading motivation and reading habits. Journal Reading and Writing, 28(4), 545-569.

McGeown, S. P., Norgate, R., \& Warhurst, A. (2012). Exploring intrinsic and extrinsic reading motivation among very good and very poor readers. Educational Research, 54(3), 309-322.

Medford, E., \& McGeown, S. (2011). Cognitive and motivational factors for reading: The need for adomain specific approach to motivation. In J. N. Franco \& A. E. Svensgaard (Eds.), Handbook on psychology of motivation: New research (pp. 187-208). Hauppauge, NY: Nova Science Publications.

Mol, S. E., \& Bus, A. G. (2011). To read or not to read: A meta-analysis of print exposure from infancy to early adulthood. Psychological Bulletin, 137(2), 267-296.

Mol, S. E., \& Bus, A. G. (2011). To read or not to read: A meta-analysis of print exposure from infancy to early adulthood. Psychological Bulletin, 137(2), 267-296.

Morgan, P. L., \& Fuchs, D. (2007). Is there a bidirectional relationship between children's reading skills and reading motivation?. Exceptional Children, 73(2), 165-183.

Nurhadi. (2016). Strategi meningkatkan daya baca. Jakarta: Bumi Aksara.

OECD. (2013). PISA 2015 draft mathematics framework. Retrieved from OECD: http://www.oecd.org

Pitcher, S. M., Albright, L. K., DeLaney, C. J., Walker, N. T., Seunarinesingh, K., Mogge, S. (2007). Assessing adolescents' motivation to reading. Journal of Adolescent and Adult Literacy, 50(5), 378396.

Sears, S. J. (2002). Contextual teaching and learning: A primer for effective instruction. Bloomington, IN: Phi Delta Kappa Educational Foundation.

Sears, S. J., \& Hersh, S. (2000). Best practices in contextual teaching and learning: Program profiles and cross-profile analysis. Columbus: The Ohio State University.

Shamsid-Deen, I. (2006). Contextual teaching and learning practices in the family and consumer sciences curriculum. Journal of family and Consumer Sciences Education, 24(1), 14-27.

Smith, B. P. (2010). Instructional strategies in family and consumer sciences: Implementing the contextual teaching and learning pedagogical model. Journal of Family and Consumer Sciences Education, 28(1), 23-38. 
Sumiati \& Asra. (2007). Metode Pembelajaran. Bandung: Wacana Prima.

Taboada, A., Tonks, S. M., Wigfield, A., \& Guthrie, J. T. (2009). Effects of motivational and cognitive variables on reading comprehension. Reading and Writing: An Interdisciplinary Journal, 22(1), 85-106

Wang, J. H., \& Guthrie, J. T. (2004). Modeling the effects of intrinsic motivation, extrinsic motivation, amount of reading, and past reading achievement on text comprehension between US and Chinese students. Reading Research Quarterly, 39(2), 162-186.

Wigfield, A., \& Eccles, J. S. (2000). Expectancy-value theory of achievement motivation. Contemporary Educational Psychology, 25(1), 68-81.

Zahri, T. N., Yusuf, A. M. \& Neviyarni, S. (2017). Hubungan gaya belajar dan keterampilan belajar dengan hasil belajar mahasiswa. Jurnal Konselor, 6(1): 18-23. 